\title{
Nature in American Transcendentalism
}

\author{
Alireza Manzari ${ }^{1}$ \\ ${ }^{1}$ English Department, Islamic Azad University, Mashhad Branch, Iran \\ Correspondence: Alireza Manzari, English Department, Islamic Azad University, Mashhad Branch, Iran. Tel: \\ 98-915-104-1139. E-mail: alireza_manzari@yahoo.com
}

Received: June 3, 2012

Accepted: June 25, $2012 \quad$ Online Published: August 21, 2012

doi:10.5539/ells.v2n3p61

URL: http://dx.doi.org/10.5539/ells.v2n3p61

\begin{abstract}
According to Emerson, an individual has to improve himself through nature, but at the same time, he emphasized that he needs to interact with his society to be a "whole man". In other words, not only nature but also society is both significant for an individual "each fit reproduces the other". According to the philosophy that Emerson founded immersion in the nature is necessary for the improvement of individual, while engagement with the society is indispensable. In other words, only through focusing on both can we live a complete life and make a better society to live in. Thoreau and Emerson emphasized on the transcendentalist idea of human harmony with nature. They believed that nature can help us improve spiritually and help us connect to the rest of the world. According to Transcendental ideas, everything is connected, everything is one. This article tries to delve more deeply into the nature from the view point of American Transcendentalism.
\end{abstract}

Keywords: transcendentalism, nature, over-soul, Emerson, Thoreau

\section{Introduction}

As an outstanding political, philosophical, and literary movement, American Transcendentalism grew during the first half of Nineteenth century. What Transcendentalists believed in was a bond between God and the world, and that God is the origin of everything in nature. Ralph Waldo Emerson as a prominent transcendental figure gained a global fame as he believed that leading the life of a hermit is the genuine way of living; this came as a result of his well-known philosophy of nature. According to his doctrines, one of the necessities of exploitation of an individual is immersion and this is done along with social interactions. Not only Emerson's philosophy covers natural aspects, but also they highly regard social matters.

During his whole life, Emerson practiced promoting his ideals which mainly revolved around transcendentalism. Aligned with the fact that immersion in nature and social concern are opposing one another, he believed in the formation of his transcendental vision upon these two, indeed. To put it simply, a visionary life and an ameliorative society are non-sense unless men dedicate themselves to both simultaneously.

According to transcendentalists, acknowledging the intimate relation between God, humanity and nature makes human potentially realizable.

"Above all the Transcendentalists believed in the importance of a direct relationship with God and with nature," stated Leslie Perrin Wilson (2000).

According to transcendentalists, a direct relationship with God and nature is significantly important. Theodore Parker spoke of man's relation to God in particular in his powerful sermon "A Discourse of the Transient and Permanent in Christianity":

In an age of corruption, as all ages are, Jesus stood and looked up to God. There was nothing between him and the father of all; no old world... no sin or the perverseness of the finite will. ... He would have us do the same; worship with nothing between us and God; ... and we never are Christians as he was the Christ, until we worship, as Jesus did, with nothing between us and the Father of all (Stanley, 1994, p.181).

Moreover, Stanley Cavell, Professor Emeritus at Harvard, revealed another dimension of Transcendentalism via identifying Emerson and Thoreau as "the founders of American thinking", while being "philosophically repressed in the culture they founded" on the other hand.

Publishing works concerning nature and self-reliance, Ralph Waldo Emerson and Henry David Thoreau as well as Walden took the United States to the forefront of the transcendentalist movement. Suppressing the common at 
the time doctrine of materialism, their notions expressed a desire for freedom from artificial limits. Through a thorough exploration of nature, human beings would come to know the truth of the globe and consequently they become better. As the leader in the movement of transcendentalism and the first American author to influence European thought, Ralph Waldo Emerson clearly expressed the concept of transcendentalism in the essay Nature which directly illustrated gaining insight spiritual cleansing simply from experiencing the nature itself. He, additionally, exhibited the importance of returning to reason and faith in nature. In other words, this explicitly demonstrated the root of humankind in nature and how Over-Soul one can feel by simply enjoying outdoors. As Emerson (2008) remarked:

Standing on the bare ground-my head bathed by the blithe air and uplifted into infinite space-all mean egotism vanishes. I become a transparent eyeball: I am nothing; I see all; the currents of the Universal Being circulate through me; I am part or parcel of God (p. 32).

These reveal the getting of purity and knowledge through a union and understanding of nature as transcendentalists believe. Being the ritual plot of poems and essays by transcendentalists, the mutual correlation between the character and nature play a crucial role in maintain the character's well being. Comprehending things beyond the normal comprehension of man is one of the outcomes of studying nature which states living proper with the universe.

\section{American Transcendentalism and Nature}

Transcendental interpretation of nature affected American literature of the era markedly, in particular the works of Nathaniel Hawthorne, Herman Melville, and Walt Whitman. Furthermore, various ministers as well as reformers and writers of the period were associated with the movement. Emerson, Thoreau, and Whitman view nature as the accumulation of all the knowledge needed to be digested and in case of in depth care and analysis, profound philosophies and identities can be formed in terms of the worldwide physical and mental sense of well being.

Henry David Thoreau was one of the first environmentalists in American history. Despite outlining the beauty of having a small proximity to nature, Walden most importantly plots is the notion of living simple. Being born and growing up in Concord, Thoreau went to living at Walden Pond in 1845 for the purpose of intensely experiencing nature and testing his transcendental outlook in the concrete physical world. In the world chapter entitled "Solitude" he illustrated his relation with nature as an intimate mutual one:

The indescribable innocence and beneficence of Nature, -of sun and wind and rain, of summer and winter, -such health, such cheer, they afford forever! ... Shall I not have intelligence with the earth? Am I not partly leaves and vegetable would myself? (Thoreau, 2004, p.58)

Thoreau in his book Walden mentioned man as an "inhabitant" in nature:

I wish to speak a word for Nature, for the absolute freedom and wildness, as contrasted with the freedom and culture merely civil-to regard man as an inhabitant, or a part and parcel of Nature, rather than a member of society... Let me live where I will, on this side is the city, on that the wilderness, and ever I am leaving the city more and more, withdrawing in the wilderness (Thoreau, 2004, p.58).

Thoreau's main theme was the idea beyond reality, beyond nature existence and human. There is a higher truth operating in the universe. Reality or nature in particular, symbolizes this higher truth, and, from its particulars, universal law may, to some degree, be comprehended. Unity of man, nature, and heaven are clearly expressed by Thoreau. Following a description of moth cocoons resembling leaves suspended over the edge of the meadow and the river, he wrote in his journal entry for February 19, 1854:

... it is startling to think that the inference has in this case been drawn by some mind that, as most other plants retain some leaves, the walker will suspect these also to. Each and all such disguises ... remind us that not some poor worm's instinct merely, as we call it, but the mind of the universe rather, which we share, has been intended upon each particular object. All the wit in the world was brought to bear on each case to secure its end. It was long ago, in a full senate of all intellects, determined how cocoons had best be suspended, -kindred mind with mine that admires and approves decided it so (Thoreau, 2002, p.302).

The meaning of nature is sought after throughout the entire Thoreau's writings, illustrated as painstaking detail and broad generalization. Both Emerson and Thoreau's writing demonstrated a close correlation between vitality of comprehending nature and perceiving the truth. Seeking after the universe, Thoreau approached the nature at Walden Pond himself which thereafter, led him to reach "looking through and beyond the nature" by the help of observing it closely (Thoreau, p.302). His affection towards nature exceeded emotional appreciation in a way that he embraced its harshness as well. He said in "Walking," "a personality so vast and universal that we have 
never seen one of her features." Unless one has the perception and manifestations of the universal in the observable world, "great awakening light" does not become possible despite being conscious of the prominent gap between inspiration by persistent knowledge of nature and fruitless preoccupation with masses of scientific detail. He observed the danger of becoming "dissipated by so many observations" (Thoreau, p.302), and figured out his own tendency to be deviated from the eternal objective. On August 19, 1851, Thoreau wrote in his journal:

I fear that the character of my knowledge is from year to year becoming more distinct and scientific; that, in exchange for views as wide as heaven's cope, I am being narrowed down to the field of the microscope. I see details, not wholes nor the shadow of the whole (Thoreau, 2002, p.303).

Thoreau got aspiration through transcending the distractions of routine life and of focusing on what was important since he was full of wonder and appreciation. Approaching loftier revelations, his excursions in Concord and beyond were made through nature. To him, nature was nothing but a particular tonic to the human spirit in an age devoted to commerce, politics, and the spread of industrialization and urbanization in a dehumanizing manner, as well as unfulfilling social interactions and to the perpetuation of human institutions at best in need of change, at worst immoral. His essay "Walking" is a coherent expression of the power of nature and "wildness", as he puts it for the purpose of expanding mankind's vision via "preservation of the world". He wrote:

If the heavens of America appear infinitely higher, and the stars brighter, I trust that these facts are symbolical of the height to which the philosophy and poetry and religion of her inhabitants may one day soar. At length, perchance, the immaterial heaven will appear as much higher to the American mind, and the intimations that star it as much brighter? (Thoreau, 1977, p.98)

The main notion of Transcendentalism as over-soul, i.e. his expression of oneness through nature, encompasses a frame formed within a direct relation with God and nature. In other words, it is a cosmic unity man, God, and nature. Emerson (2011) wrote an essay titled "The Over-Soul", he explained the over-soul as:

...that great nature in which we rest ... that Unity, that Over-Soul, within which every man's particular being is contained and made one with all other. ... We live in succession, in division, in parts, in particles. Meantime within man is the soul of the whole; the wise silence; the universal beauty, to which every part and particle is equally related; the eternal ONE (p.126).

Rooted in the ancient philosophy of Plato, the concept of "The Over-Soul", it is the divine spirit or mind present in each and every man and in all of nature having an all-pervading, omniscient, supreme mind. Divine mind is reflected through each and every specific sample of humanity to the point that the globe is and can be extrapolated from each sample. Man can discover all universal laws at work from within God's manifestation illustrating a direct perception of God and openness to the natural world avenues to self-understanding through the presence of the divine spirit in both nature and the human soul. Self-understanding results in the perception of higher truth.

According to Emerson, Over-soul is present both in human beings and nature and acts as the divine spirit. Self-knowledge and harmony are reached by discovering and merging oneself with spirit shared by the universe, i.e. Over-soul, acting as self-discovery as well. Emerson later described his understanding of Nature and Nature's relationship to the divine:

In the woods, we return to reason and faith. There I feel that nothing can befall me in life-no disgrace, no calamity ... A leaf, a drop, a crystal, a moment of time is related to the whole, and partakes of the perfection of the whole. ... So intimate is this Unity, that, it is easily seen, it lies under the undermost garment of nature, and betrays its source in the Universal Spirit (Emerson, 2008, p.15).

In Nature, Emerson (2008) first expressed his pantheistic view of the world:

Nature is the place where God can be found, he wrote. Nature is thus sacred; it is a source of nourishment, of beauty and inspiration. It is in Nature, therefore, and in Nature alone, that man can find what he needs: it is where God speaks to him; it is where man can regenerate himself, without the help of traditional, institutional religion-since his only religion, indeed, is Nature (p.17).

As a result, in order to find the true self mankind must look for it in nature. Despite the influence that Unitarianism first had on his thought, Emerson strictly repudiated his former Unitarian school and joins nature doctrines. Promoting a different look toward nature, Emerson mentioned: man, just like him, must learn to open his eyes, as if for the first time in his life, and must learn to look at the world differently, getting rid of his preconceptions and of his moral or educational influences. 
Looking for a divine feeling in nature, Emerson found unity of life by letting himself open to it and this unity between nature and mankind is the universal spirit, God, the Over-soul. This, God in particular, has led to various perceptions by different ministers, biographers, and Unitarian Universalists. Robert D. Richardson, author of Emerson, A Mind on Fire, described Emerson as a pantheist: "Pantheism is the view that everything is of an all-encompassing immanent abstract God; or that the Universe, or nature, and God are equivalent." (Richardson, 1966, p.27)

According to Emerson, ideas are real, whereas the material is nothing more than an illusion. He regards the beauty of nature as "the herald of inward and eternal beauty" (Emerson, 2008, p.21). This reflects the inner spiritual world and its moral laws, the objects in the outer material world have a mutual correlation with spiritual laws; discovering of which boosts knowledge; as an instance, proverbs use something material to express something spiritual:

A rolling stone gathers no moss; A bird in the hand is worth two in the bush; ... Make hay while the sun shines (Emerson, 2008, p.21).

The less proximity that one has to nature, the closer they can perceive the world behind the scenes. If an individual obtains the capability of observing nature in a proper manner, he/she will be exposed to a world being recreated, transformations as the spirituals change him/her. Transcendentalists believed that the natural world can draw forth the latent energies of the soul and thereby, can read the secrets of a soul through regarding the nature as a living book. Sampson Reed in a book entitled "Oration on Genius", explained:

If we choose to express any natural truth in physical and definite vocal terms, and to convert these terms only into the corresponding and spiritual terms we shall by this means elicit a spiritual truth. ... in the place of the physical truth. ... (Perry, 1957, p.50)

Everyone interacts with the outer world including but not limited to rivers, lakes, forests, etc. but only the genius of the mind manage to figure out its inner essence which indeed, helps them comprehend the Unity of Spirit and Nature whose thorough investigation leads to a metaphysical significance.

Eliminating all the dogmas, transcendentalists fuse God and Nature into the one substance of the transcendental imagination. Emerson (1960) writes in his Journal:

Still am I a poet in the sense of a perceiver and dear lover of the harmonies that are in the soul and in matter, and especially of the correspondence between these and those (p.73).

Emerson, in "Transcendentalist" equated Transcendentalism with Idealism differentiating it from Materialism. Opposed to the materialists' thinking of assuming the world of senses as final, from an idealist point of view, it has a metaphysical basis, an invisible and unsounded center within human. Materialists stress on facts and history while idealists stress on the power of thought, inspiration etc. In case of putting a metaphysical basis for external facts, they are supposed important by idealists. Symbolizing nature as a spirit, Emerson finds studying nature motivational and description-free. A tranquil sense of unity is reachable only through looking at the landscape for Emerson as he draws in his essay on Nature:

the soul holds itself off from too trivial and microscopic study of the universal tablet. It respects the end too much to immerse itself in the means (Emerson, 2008, p.24).

This illustration results in a theoretical observation of nature. An entry in his Journal, he confirmed this:

Frogs pipe; waters far off tinkle; dry leaves hiss; grass bends and rustles, and I have died out of the human world and come to feel a strange cold, aqueous, aerial ethereal sympathy and existence ... (Emerson, 2008, p.24).

Hence, Nature is the proper place for self-recovery, for sublime thoughts and this does not require in-depth observation or description of natural objects. Joan Burbick (1987) also quoted this aspect of Emerson's writings:

Perception for Emerson often became equivalent to contemplation and necessitated the absence of both landscape and the objects of sight. He consciously avoided description and observation as obstacles to seeing correctly. Nature was mainly a symbol not a fact (p.7).

Emerson and Thoreau differ in the way that while the former observes thoughts, the latter examines experiences and this is prominent in Emerson's own remark in his journal on Thoreau. He expressed that:

Thoreau gives me, in flesh and blood and pertinacious Saxon belief, my own ethics. He is far more real, and daily practically obeying them, than I, and fortifies my memory at all times with an affirmative experience which refuses to be set aside (Emerson, 1960, p.24). 
Henry David Thoreau had the same idea with Emerson when he said:

I went to the woods because I wished to live deliberately, to front only the essential facts of life, and see if I could not learn what it had to teach, and not, when I came to die, discover that I had not lived (Thoreau, 2004, p.273).

His belief is opposing the idea that Earth is dead as just strata to be observed by scientists and considered as history, but is alive and changing. To him, nature is analyzed for its own sake not for the things it produces. He outlined the fact that farming had been made into a means of making money which takes out its holy purpose as the farmer "knows Nature but as a robber" and had lost his sacred relationship to the land.

Similar to Emerson, Thoreau stressed nature as a prevailing factor playing a significant role between nature and man. According to his thoughts, nature teaches lessons not learnt in any other way. In his work entitled "Walking", Henry David Thoreau (1975) illustrated the greatness of nature as: "I believe that there is a subtle magnetism in Nature, which, if we unconsciously yield to it, will direct us alright" (p.5).

Via this statement, Thoreau explained that nature is capable of redirecting us onto the correct path which is really something of greatness.

In terms of man's interaction with nature, Henry David Thoreau (1975) said that:

The trees and shrubs rear white arms to the sky on every side; and where walls and fences, we see fantastic forms stretching in frolic gambols across the dusky landscape, as if Nature had strewn her fresh designs over the fields by night as models for man's art (p.5.)

He also stated that by art, mankind is seeking to spread nature so as to proudly exhibit it.

For Wilber, Emerson's profound "nature mysticism" put a distinct line between nature and Spirit, but neither dissociates nature from nor equates nature with Spirit clarifying that the unity of the world is in its transcendental realm. In his "Over Soul", he wrote: "We live in succession, in division, in parts, in particles. Meantime within man is the soul of the whole; the wise silence; the universal beauty, to which every part and particle is equally related; the eternal ONE ..." (Emerson, 2011, p.126).

Nature encourages Thoreau's quest for simplicity and assists him with regaining an innocence lost in the world of civilization. "I have always been regretting that I was not as wise as the day I was born" (Thoreau, 2004, p.98), as he put it. Feeling close to nature, he outlines supportiveness and friendliness of one as wild and uncivilized as his true self that interacts within nature. Therefore, his belief revolves around having access to nature for the purpose of nurturing their relation with the higher self within, in particular for those residing in urban areas.

Defending the divinity of all human souls, through further questioning the institutionalized religions or socially-prescribed ethics, leads to insubordination of nature and God to the opinions of humankind. The base of any established religious or ethical code by society is indeed at odds with nature: "The devotee flouts nature." (Emerson, 2008, p.29) Social standards and those "commencing from man" (Emerson, 2008, p.29) take the advantage of an individual's moral code, that is, its foundation and inspiration in nature. Religions and ethics created for the mass are deceiving, for "they both put nature underfoot" (Emerson, 2008, p.29). Only the individual has the ability to gain the ideal moral ethic through nature. This way, Emerson solved his personal religious crisis by rejecting institutionalized religion altogether in favor of an individual moral philosophy inspired by the nature itself.

He illustrated the morality of the individual not only via natural imagery but through the use of nature as a symbol of the individual's potential for growth and renewal. Throughout Nature, Emerson debated images of land and farming figure into as an abstract notion of nature and the soul and to him, signifying Transcendentalism's tangible ties to the earth could not demonstrate the need for spiritual and intellectual regeneration but the indicators were these natural images.

Using symbolic images of the land and other regenerative properties of nature to signify how humanity reconnected with nature, Emerson sought restoration whose "floods of life stream around and through us" excite an influx of human development (Emerson, 2008). Observing signs of birth, growth, and development, he reconnects humanity with nature as an inevitable preoccupation of life as well as vigor: "In the woods is perpetual youth" (Emerson, 2008, p.32). Ensuring the soul's regeneration can be achieved by a return to nature and hence, "there is more wool and flax in the fields" (Emerson, 2008, p.32) not only does present the bounty of the land available to humanity but also illustrates the bounty of humanity itself. To put it simply, the wool is the "poetry and philosophy of insight" (Emerson, 2008, p.32) and the flax a "religion by revelation" (Emerson, 2008, p.32). The fields, ripe for reaping, act as human mind's objectives as Emerson (2008) put it: "new lands, new men, and new thoughts" (p.35) demands the restructuring of the human soul rather than the world not a literal 
call for new lands or social reconstructions.

Alongside his utilization of natural descriptions for the purpose of demonstrating regeneration, he employed pastoral, rustic imagery in an attempt to elevate the laborer which is not an expression of class concern or of the advantage of agrarianism but seeks depicting the laborer as a symbol of the necessity and dignity of all work. Aiming in expanding the laborer with the inherent dignity in all individual work and referring this to what he saw as a dynamic relationship between nature and progress, he outlined human progress as a participation of all individuals: "A man is fed, not that he may be fed, but that he may work" (Emerson, 2008, p.32). In turn, nature offered itself as a resource to labor: "It [nature] offers all its kingdoms to man as raw material which he may mould into what is useful. Man is never weary of working it up" (Emerson, 2008, p.36). Therefore, human growth requires a mutual cooperation between the resources of nature and individuals' work. Emerson discussed that human development is an inevitable outcome of the labor of humanity and the "steady and prodigal provision that has been made for his support and delight on this green ball which floats him through the heavens" (Emerson, 2008, p.38). He saw nature everywhere as a means to simplify humanity's development: "Beasts, fire, water, stones, and corn serve him" (Emerson, 2008, p.32). And this not only does ensure humanity's survival, but also helps it soar and thrive, metropolises and all:

To diminish friction, he [mankind] paves the road with iron bars, and, mounting a coach with a ship-load of men, animals, and merchandise behind him, he darts through the country, from town to town, like an eagle or a swallow through the air. By the aggregate of these aids, how is the face of the world changed, from the era of Noah to that of Napoleon! The private poor man hath cities, ships, canals, bridges, built for him. He goes to the post-office and the human race run on his errands; to the book-shop, and the human race read and writes of all that happens, for him; to the court-house, and nations repair his wrongs. He sets his house upon the road, and the human race go forth every morning, and shovel out the snow, and cut a path for him (Emerson, 2008, p.39).

Humanity constructs cities and inhabits it through nothing but nature. Nature's complicity in human affairs roots the concept of labor not only as an inevitable part of human existence, but as a crucial one indeed. Whether rural or urban, Emerson admired labor for its role in the mutually beneficial interaction of human and nature, and he demands a new age alongside industry, business, trade, machinery, and urban development. Although he explicitly admired nature and its typical designation, "essences unchanged by man" (Emerson, 2008, p.32), his philosophies do not root within a forest or field. He also stressed all artificial things, "the mixture of his [man's] will with the same things" (Emerson, 2008, p.32).

Unless a mutual cooperation of humanity and nature towards progress is not achieved, one can regard all labor as noble. On the other hand, he questions the possibility of an individual being able to maintain a relationship with nature without tipping the balance in favor of humanity. The individual soul, and not society, can alone manage to handle a transformative balance: "The problem of restoring to the world original and eternal beauty is solved by the redemption of the soul. [...] The reason why the world lacks unity, and lies broken and in heaps, is that man is disunited with himself" (Emerson, 2008, p.32).

Ralph Waldo Emerson (2006) in his "Nature" added a third viewpoint as man's involvement in nature. He said that "Nature is so pervaded with human life, that there is something of humanity in all, and in every particular" (p.19). Via his involvement, Emerson believed that man has tainted nature and has been tampered too much.

Associating the importance of nature to man, Ralph Waldo Emerson (2008) implied in "The Method of Nature" that "In the absence of man, we turn to nature, which stands next. In the divine order, intellect is primary; nature, secondary; it is the memory of the mind" (p.19). To him, in a divine order nature has precedence over man as without nature there would be no man; i.e. nature is more involved in the life of man than man is involved in nature. Emerson (1960) figured out that "nature in the woods is very companionable. There, my Reason \& my Understanding are sufficient company for each other" (p.392). Thoreau expressed "we are enabled to apprehend at all what is sublime and noble only by the perpetual instilling and drenching of the reality that surrounds us" (Thoreau, 2004, p.159).

Emerson found out that nature is the symbol. Unlike his predecessors who used to take nature as a metaphor to explain that the world is alive, Emerson, similar to the Puritans, pointed out that the world is alive and nature is the evidence; nature is neither a simile nor a metaphor. Emerson (2008) in his Nature remarked:

Beyond all this universality of the symbolic language, we are apprised of the divineness of this superior use of things, whereby the world is a temple whose walls are covered in emblems, pictures and commandments of the Deity, -in this, that there is no fact in nature which does not carry the whole sense of nature; and the distinctions which make in events and in affairs, of low and high, honest and base, disappear when nature is used as a symbol (p.20). 


\section{Conclusion}

In Emerson's essay entitled "Nature" composed in 1836, there exists a chapter on Beauty which begins with an emphasis on world's beauty which is distinct from many contemporary discussions of beauty. He regarded that two things contributing to beauty: firstly, the constitution of things in nature and secondly, the capacity of the human eye to form what it sees. Consequently, a pleasure is obtained from what Emerson called "primary forms" which seem to be major form types in nature, i.e. sky, mountain, tree, and animal; acting as if he is a formalist: what gives us pleasure is "outline, color, motion, and grouping." He observed nature in an analogous way to that of an artist's. As an instance, he referred to the eye as "the best of artists" in its shaping of nature. The eye in conjunction with the laws of light produces something else important to the typical landscape artist: perspective. Acting a crucial social role, artists shape an object beautifully not simply for pleasure, but as part of the creation by God. As a matter of fact, neglecting to observe the surroundings as the accurate symbol of the God's manifestation, Emerson (2004) warned us of gradually losing the capability of creating expressive things:

Nature offers all her creatures to [the poet] as a picture language...Things admit of being used as symbols because nature is symbol, in the whole and in every part. Every line we draw in the sand has expression; and there is no body without its spirit or genius (p.266).

To him, artists are not parallel creators to God, but are as a part of God. This means that everything the artist makes truly beautiful is a manifestation from God that is part of His continual Creation and, hence, the various types of art are all components of one universal emanation of Creation. Emerson's poetry manages to seek the fundamental forms of realizing the existence of beauty. "We carve and paint, or we behold what is carved and painted, as students of the mystery of Form." (Emerson, 2004, p.165)

On the other hand, Henry David Thoreau reminded us that the world was created beautiful from the beginning and that namer, and represents beauty. For the God and Beauty is one in the same. The poet is a mediator who translates beauty and God's creation into an intelligible object. The poet is the sayer, the world is not painted or adorned, but is from the beginning beautiful; and God has not made some beautiful things, but Beauty is the creator of the universe. For Emerson, pictures were the first formulation of expression not the words. However, the artist must employ the symbols in use in his day and nation to convey his enlarged sense to his fellow-men. And hence, new art is born of the former (Emerson, 2011, p.119).

Most directly, Emerson dealt with aesthetics in "Art". The plot addressed "The Poet," which is essentially the same figure for Emerson. Similar to the poet, the artist employs imagination to find the living spirit that seeks creating beauty. In order to design a truly beauty, it must come from a mind in communion with God since the artist and poet express out of the force of Creation. Due to the development of the soul, it almost never repeats itself, but every time tries producing a new and fairer whole which is shown in both the useful and fine arts works, if we employ the popular distinction of works according to their aim either at use or beauty. Thus in our fine arts, the main objective is creation rather than imitation (Emerson, 2011, p.119).

Producing from his imagination to present the essence of the object, if the artist fails to see the originating spirit, the essence of the form or fails to present the essence in the work, then the art has been deteriorated. Plato believed that the artist only imitates nature and any imitation is inherently a less pure form of the original; hence, this is a development from that critique. Imitation is a caricature of the natural object without including its purpose. It does not give anything to the good of society or life. In Emerson's belief, an art work is not good enough not due to imitation, but in case the act of the artist's creation tends to hide the essence. The act of creation also provides a purpose for the object, for it is a part of a greater work. Just as God created the world where everything has a purpose; the artist creates objects as part of the use for all creation. The connection between the useful and the beautiful has been discussed numerously in his writing about aesthetics so as they have to be free of distinction between the useful arts and the fine arts; in other words, there should be no distinction between the practical and the poetic. Since 1830s, American authors began an evolutionary development by following this viewpoint as part of a corpus of writing about aesthetics. Beauty must come back to the useful arts, and the distinction between the fine and the useful arts be forgotten. In nature, everything is useful and thereby beautiful. Being is alive, moving, and reproductive stands for its beauty; and being symmetrical and fair outlines its usefulness (Emerson, 2011, p.120).

Moreover, Emerson mentioned a moral and social benefit of all art. Art was never to be done simply for art's sake. There was always to be a higher purpose: art as a means of elevating the human condition. Not only did Emerson in his essay Nature but also others in various writings argued that the similarity of landscape (nature) to a book to be read. Human race, if they want, can manage to grasp a comprehension from the natural environment, and everyone could to some extent be a judge of beauty and a critic of art. Emerson also believed that the level 
of this understanding was higher among artists than the average person. Artists were capable of seeing and understanding the world and its depth of meaning with more clarity. But with that gift of perception also came a responsibility to communicate that greater understanding to the populace at large.

As Emerson wrote, the artist "must work in the spirit in which we conceive a prophet to speak or an angel of the lord to act". The artist had a moral imperative to serve society as both a seer and sayer. Social unveiling of truths is indeed the necessity of any art and its major objective.

\section{References}

Burbick, J. (1987). Thoreau's Alternative History Changing Perspectives on Nature, Culture and Language. Philadelphia: University of Pennsylvania Press.

Cavell, S. (1994). In Quest of the Ordinary. Chicago: University of Chicago Press.

Emerson, R. W. (1960). Selections from Ralph Waldo Emerson: An Organic Anthology. Boston: Houghton Mifflin.

Emerson, R. W. (2004). Essays and Poems. New York: Fine Creative Media, Inc.

Emerson, R. W. (2008). Nature. New York: Kindle Edition.

Emerson, R. W. (2011a). Essays: First Series. Charleston: Create Space.

Emerson, R. W. (2011b). The Method of Nature: An Oration. Charleston: Nabu Press.

Miller, P. (1957). The American Transcendentalists: Their Prose and Poetry. New York: Doubleday. Parker, T. South Boston Sermon. Retrieved from http://www25.uua.org/uuhs/duub/articles/theodoreparker.html

Thoreau, H. D. (1977). The Portable Thoreau. New York. Penguin.

Thoreau, H. D. (2002). The Writings of Henry David Thoreau. Princeton: Princeton University Press.

Thoreau, H. D. (2004). Walden or, Life in the Woods. Boston: Shambhala Press.

Wilson, L. P. (2000). Thoreau, Emerson, and Transcendentalism. Foster City: IDG Books Worldwide. 